Discussion Paper No. 06-045

Hidden Champions -

How Young and

Small Technology-Oriented Firms

Can Attain High Export-Sales Ratios

Helmut Fryges

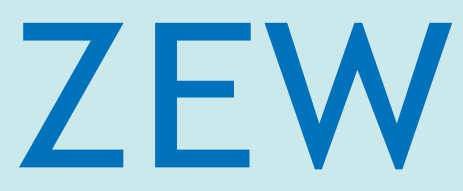

Zentrum für Europäische Wirtschaftsforschung $\mathrm{GmbH}$

Centre for European

Economic Research 


\title{
Discussion Paper No. 06-045 \\ Hidden Champions - How Young and Small Technology-Oriented Firms Can Attain High Export-Sales Ratios
}

\author{
Helmut Fryges
}

Download this ZEW Discussion Paper from our ftp server:

ftp://ftp.zew.de/pub/zew-docs/dp/dp06045.pdf

Die Discussion Papers dienen einer möglichst schnellen Verbreitung von neueren Forschungsarbeiten des ZEW. Die Beiträge liegen in alleiniger Verantwortung der Autoren und stellen nicht notwendigerweise die Meinung des ZEW dar.

Discussion Papers are intended to make results of ZEW research promptly available to other economists in order to encourage discussion and suggestions for revisions. The authors are solely responsible for the contents which do not necessarily represent the opinion of the ZEW. 


\section{Non-technical Summary}

Determinants of a firm's export-sales ratio (degree of internationalisation) are frequently discussed in the literature related to individual firms' export activities. Stylised facts show a positive relationship between firm size and the firm's export-sales ratio. In fact, a number of econometric studies find a positive effect of firm size on the firm's export-sales ratio. However, recent empirical results have revealed that it is not size per se that leads to a high degree of internationalisation. When the econometric model controls for (unobserved) firm heterogeneity, the positive effect of firm size on the export-sales ratio vanishes. This result is in line with the anecdotal evidence that many small firms are highly successful on the foreign market and generate a relatively high share of their total sales abroad. Hermann Simon calls these small but internationally successful firms "hidden champions." Small technology-oriented firms in particular often occupy narrow market niches, in which they are world or European market leaders.

In addition to smallness, youth is often regarded as an obstacle to realising a high export-sales ratio. It is often argued that older firms have learnt how to successfully conduct business and how to adjust business strategies to foreign environments. A firm's degree of internationalisation is therefore expected to be positively correlated with firm age. However, research on "born globals," in particular on those operating in high-tech sectors, calls the hypothesis of a positive relationship between a firm's age and its degree of internationalisation into question. "Born globals" enter the international market immediately or soon after inception, and some of them rapidly generate a high percentage of their total sales abroad.

This paper examines the export-sales ratio of a sample of German and British technology-oriented firms founded between 1987 and 1996, inclusive. The firms were contacted using two surveys conducted simultaneously in Germany and the UK in 1997 and 2003. Both in 1997 and 2003, just under three-quarters of the sample's firms had international sales. While the participation rate in the international market increased only slightly from 1997 to 2003, the group of exporters in our sample expanded their international business activities significantly, raising the average degree of internationalisation from $33 \%$ in 1997 to $43 \%$ in 2003 , which mirrors the rising globalisation on high-tech markets.

The key result of this paper is that neither youth nor smallness is necessarily an obstacle to realising a high export intensity. However, to do so requires that the firms possess firm-specific assets in order to overcome barriers to entry into the foreign market. These firm-specific assets may be acquired via conducting R\&D activities, buying novel technology from other companies, or by employing internationally experienced managers. On the other hand, the optimal degree of internationalisation is negatively influenced by the requirement of intense product customisation. 


\title{
Hidden Champions - How Young and Small Technology-Oriented Firms Can Attain High Export-Sales Ratios
}

\author{
by \\ Helmut Fryges**
}

June 2006

\begin{abstract}
Determinants of a firm's export-sales ratio (degree of internationalisation) are frequently discussed in the literature related to individual firms' export activities. Stylised facts show a positive relationship between firm size and firm age on the one hand and the firm's export-sales ratio on the other hand. However, anecdotic evidence and recent empirical results revealed that it is not size or age per se that leads to a high export-sales ratio. This paper analyses the export-sales ratio of a sample of young technology-oriented firms in Germany and the UK. The empirical results confirm that neither youth nor smallness are necessarily an obstacle to realising a high degree of internationalisation. However, this requires that the firms possess firm-specific assets in order to overcome barriers to entry into the foreign market. These firm-specific assets may be acquired via conducting own R\&D activities, buying novel technology from other companies, or by employing internationally experienced managers.
\end{abstract}

Keywords: High-technology industries, export-sales ratio, fractional logit model.

JEL Classification: F23, L60, L86

* I gratefully acknowledge financial support from the HSBC Innovation and Technology Group and the Anglo-German Foundation for the Study of Industrial Society. Helpful suggestions by Joachim Wagner are also gratefully acknowledged. I thank Marc Rennert, Martin Becker, Natalie Gaier, Stefan Hoffmann, and Thea Platz for their competent research assistance and Andrew Flower for proofreading. Special thanks go to Marc Cowling and Gordon Murray for carrying out the survey this study is based on in the UK. Any remaining errors are my own.

** Centre for European Economic Research (ZEW), Department of Industrial Economics and International Management, P.O. Box 103443, D-68034 Mannheim, Germany, e-mail: fryges@zew.de 


\section{Introduction}

For small high-tech firms international orientation is regarded as crucial for growth and long-term survival. The 2002 Observatory of European SMEs (European Commission 2002) highlighted that in 1998/1999, 65\% of all high-tech small and medium-sized enterprises (SMEs) from ten European countries had international sales and received $19 \%$ of their turnover from sales abroad. Since it is often argued that sales potential in European domestic markets is insufficient for the amortisation of high product research and development costs (see, e.g., McDougall et al. 1994, Bürgel et al. 2004), international business activities are expected to help European SMEs amortise R\&D costs, thereby enabling them to fulfil the expectation related to them with respect to structural change, innovation, and job creation.

Within the larger group of high-tech SMEs, the interest of economists and politicians is focused in particular on newly founded, technology-based firms (NTBFs). NTBFs constitute the smallest players in high-tech sectors, leading to the question how they can cope with the challenges posed by high-tech markets. Entering the international market might be regarded as one of the greatest challenges faced by small and newly founded firms, but it is now established knowledge that NTBFs are often internationally active shortly after their inception (“infant multinationals," Lindqvist 1991, “born globals,” McKinsey 1993). ${ }^{1}$

The relationship between firm size and the respective firm's degree of internationalisation (defined as the share of non-domestic revenues; Sullivan 1994b) is frequently discussed in the related literature. ${ }^{2}$ A number of studies revealed a positive relationship between firm size and the firm's export intensity. However, Wagner (2003) proved that it is not size per se that leads to a high export-sales ratio. If he controls for unobserved firm heterogeneity, the positive effect of firm size on the export-sales ratio vanishes. Wagner's results are in line with the anecdotic evidence that many small firms are highly successful on the foreign market and generate a relatively high share of their total sales abroad. Simon (1996) illustrated this fact by a number of outstanding examples and called these small but internationally successful firms "hidden champions.” NTBFs in particular often occupy narrow market niches, being world or European market leaders in their niches.

1 In this paper, only firms that export their products or services are regarded as internationally active firms. This means that only internationalisation on the sales market is considered. Although an internationalisation on the procurement market may also be important for small high-tech firms, it is neglected in the following.

2 The expressions “degree of internationalisation,” “export-sales ratio," and "export intensity” are used interchangeably in this paper. 
In addition to smallness, youth is often regarded as an obstacle to realise a high export-sales ratio. Kaiser and Kongsted (2004), for instance, argued that older firms have learnt how to successfully conduct business and how to adjust business strategies to foreign environments. The firms' degree of internationalisation is therefore expected to be positively correlated with firm age. In fact, in early studies, the internationalisation of a firm has frequently been described as a process in which the enterprise gradually increases its commitment in the foreign market (Bilkey and Tesar 1977, Johanson and Vahlne 1977, 1990). More recently, however, research on "born globals," in particular on those operating in high-tech sectors, put the hypothesis on a positive relationship between firm age and a firm's degree of internationalisation into question. "Born globals" enter the international market immediately or soon after inception, and some of them rapidly generate a high percentage of their total sales abroad (Lindqvist 1991, McDougall et al. 1994).

Given this background, this paper analyses two related questions. Firstly, the relationship of firm size and firm age on the one hand and the firms' export intensity on the other hand will be examined using an Anglo-German sample of NTBFs. Applying the same econometric model like Wagner (2001, 2003), it will be tested whether firm size increases the export-sales ratio or whether its effect is insignificant in accordance with Wagner's (2003) analysis. This question is of particular interest since the firms in our sample employed only 26 individuals on average. Thus, they are substantially smaller than the firms analysed by Wagner. Moreover, it will be tested whether firm age has a significant impact on the export intensity of NTBFs. If firm size and firm age cannot explain the export-sales ratio of the firms in our sample this will raise the question which firmspecific factors instead of size and age enable young and small technology-oriented firms to attain high export-sales ratios. Wagner (2003) was only able to consider unobserved firm heterogeneity. It was impossible for him to determine the relevant success factors which allow a firm to realise a high degree of internationalisation. As this paper's second major focus, I will address this important question.

My empirical research is based on two surveys that were conducted simultaneously in Germany and the UK. In 1997/1998, a stratified random sample of German and UK-based NTBFs founded between 1987 and 1996 was contacted by sending out a written questionnaire (see Bürgel et al. 2004). In the summer of 2003, all surviving firms from the original sample were contacted once again by means of computer-aided telephone interviews (CATI). After performing several consistency checks, 217 companies could be retained for the econometric analyses. The empirical results confirm that neither youth nor smallness are necessarily an obstacle to realising a high degree of internationalisation. However, this requires that the firms possess firm-specific assets in order to overcome barriers to entry into the foreign market. These firm-specific assets may be acquired via 
conducting own R\&D activities, buying novel technology from other companies, or by employing internationally experienced managers.

The paper is organised as follows: Section 2 reviews the theoretical and empirical literature concerning a firm's degree of internationalisation. Section 3 describes the data used for the empirical analysis, section 4 shows some descriptive statistics. The empirical methodology is explained in section 5. The estimation results are presented and interpreted in section 6; section 7 concludes.

\section{Theoretical Considerations and Literature Review}

A prominent model in the literature on individual firms' export behaviour is the dynamic model originally formulated by Roberts and Tybout (1997) and applied, among others, by Bernard and Jensen (2004) and Bernard and Wagner (2001). ${ }^{3}$ Roberts and Tybout assume that, in period $t$, a rational firm $i$ maximises the profits $\pi_{i t}$ it receives by selling the profit-maximising level of exports $q_{i t}^{*}$ abroad. It is assumed that the firm is always able to produce the profit-maximising level of exports $q_{i t}^{*}$. The firm's profit depends on factors exogenous to the firm $X_{i t}$, such as exchange rates, and firm-specific variables $Z_{i t}$, like firm size, age, or product characteristics. Firm profit is given by

$$
\pi_{i t}\left(X_{i t}, Z_{i t}\right)=p_{t} q_{i t}^{*}-c_{i t}\left(X_{i t}, Z_{i t} \mid q_{i t}^{*}\right) .
$$

where $p_{t}$ is the price of goods sold abroad and $c_{i t}$ is the variable cost of producing quantity $q_{i t}^{*}$. According to the model, firm will export $q_{i t}^{*}$ in period $t$ if the period's profit is non-negative. Otherwise, the firm will not have any international sales and will confine itself to the domestic market. It is important to note that the decision to internationalise and the choice of the profitmaximising level of exports are made simultaneously. Consequently, both decisions are determined by the same independent variables.

Wagner (2001) outlined this relationship when discussing how to appropriately model the exportsales ratio. Since foreign market entry and the profit-maximising volume of exports are chosen simultaneously, the firm's decision-making process has to be modelled as a one-step approach. In the related literature, however, the degree of internationalisation is often examined econometrically using two-step approaches (see, among others, Wakelin 1997): In the first step, the firm

3 Formulas and notation used in this paper are identical to those used by Bernard and Jensen (2004) and Bernard and Wagner (2001). 
decides whether to internationalise or not, and in the second step the optimal volume of exports is selected. The second equation is, of course, only defined for the subsample of firms with international sales. Estimating the second step econometrically therefore demands considering the probability of being an exporter, which is determined by the first equation (i.e., a possible sample selection bias has to be taken into account; see, e.g., Greene 2000). In order to identify the first equation, two-step approaches require independent variables that can explain the decision of foreign market entry but do not affect the degree of internationalisation, that is, the dependent variable of the second equation. However, as has been argued from a theoretical point of view, a one-step approach is best to explain the degree of internationalisation, and all variables relevant to the market entry decision are also expected to influence the volume decision.

It is a well-known stylised fact that the degree of internationalisation increases with firm size. This relationship was already pointed out by Johanson and Vahlne (1990) in the context of their internationalisation process model: Large firms have enough resources to take larger internationalisation steps leading to a higher commitment in the foreign market. Wagner $(1995,2001)$ summarised further theoretical arguments as to why firm size may be important for a firm's international business activities. Larger firms can fully exploit the potential of the foreign market by realising economies of scale in production. They can profit from bulk purchasing if they are able to exploit the additional potential of the foreign market. Large firms can raise financial resources at a lower cost than small firms and are able to bear higher risks when entering into the foreign market (e.g., due to internal diversification). Finally, some costs related to a firm's international business activities are fixed costs, for example, carrying out market studies or finding a foreign distributor or agent. The larger the firm, the smaller the unit costs of these activities. On the other hand, if a firm increases its international engagement the costs of coordination will also rise and sometimes begin to escalate when some critical threshold of internationalisation is exceeded. Managers interviewed by Geringer et al. (1989) reported having to institute new organisational structures and mechanisms of control when expanding their international business activities in order to avoid a decrease in their firms' profits. ${ }^{4}$

Thus, the relationship between export intensity and firm size is expected to be positive but nonlinear and to decrease with size. Econometric studies estimating the impact of firm size on the firm's degree of internationalisation therefore contain not only a measure of firm size (e.g., the

4 The main focus of the analysis of Geringer et al. (1989) is the relationship between firm performance and the firms' degree of internationalisation, which is beyond the scope of this study. Geringer et al. found an "internationalisation threshold" beyond which firms' profit margins erode. See also Sullivan (1994a) for a thorough discussion of the work of Geringer et al. 
number of employees) but also its squared value in the regression equation. Consistent with the theoretical considerations, most studies, including Wagner (1995, 2001), Wakelin (1997), and Barrios et al. (2003), found a positively significant coefficient of firm size and a negatively significant one for its squared value. However, Wagner (2001) showed that this inversely $U$-shaped relationship is confirmed only for some but not for all manufacturing industries in Germany. Moreover, Wagner (2003) extended his own analysis by controlling for unobserved firm heterogeneity in his data set. More precisely, he applied a fixed-effects version of the fractional logit regression developed by Papke and Wooldridge (1996) (see section 5). If, however, unobserved heterogeneity was considered when estimating the model, firm size and its squared value became insignificant. Both the results of Wagner (2001) and of the same author's 2003 study suggest that it is not size per se that allows a firm to increase its export intensity. At least in some industries, smallness need not be a barrier to becoming a successful exporter. These insights are of interest in particular for the small high-tech firms in our sample. In fact, Bürgel et al. (2004) did not find an effect of (start-up) size on the export-sales ratio when estimating a Tobit model using data of those firms that participated in the first survey this paper is based on in 1997 (see section 3). ${ }^{5} 6$

In contrast to the export-size relationship, the impact of firm age on the degree of internationalisation is rarely discussed in the literature. The internationalisation process model developed by Johanson and Vahlne $(1977,1990)$ regards internationalisation as a gradual process in which firms incrementally increase their commitment in foreign markets over time. An international engagement is always associated with uncertainty. As a consequence, firms start their international activities with relatively few resources. The commitment of resources to a foreign market increases knowledge of that market and thus reduces any existing uncertainty about the foreign environment. The internationalisation process is therefore combined with a dynamic learning process over time. Similarly, Kaiser and Kongsted (2004) argue that older firms have learnt how to successfully conduct business and how to adjust business strategies to new and changing environments. This makes older firms more efficient than younger firms. Thus, it is plausible to expect that the extent of the firms' international business activities is positively correlated with firm age.

There are only few empirical studies that examine the relationship between the firms' international engagement and firm age. Analysing a sample of German manufacturing firms, Arnold and Hussinger (2005) find that firms that are ten years of age or younger are more likely to have interna-

5 The squared value of firm size, measured by (the logarithm of) the number of employees was not included in their specification (see Bürgel et al. 2004).

6 The application of the Tobit model for estimating the degree of internationalisation can be criticised from an econometric point of view. For a detailed discussion, see Wagner (2001). 
tional sales than older firms. This result contradicts the above stated hypothesis of a positive relationship between exports and firm age. The authors argue that there might be some firms in their sample that were founded with an immediate international focus (like "born globals"), leading to a higher probability of young firms to export. In contrast to the result obtained by Arnold and Hussinger, Kaiser and Kongsted (2004) find a positive effect of (the logarithmic) firm age on the probability to export of (West) German manufacturing firms. Similarly, Mañez et al. (2004) show that (the logarithmic) firm age increases the probability to export of Spanish manufacturing firms. Using data of manufacturing firms from the German state of Lower Saxony, Wagner (1996) estimates various econometric models in order to explain the firms' export intensity. However, the dummy variables that indicate different age classes are insignificant in each estimated model, rejecting the hypothesis of a positive relationship between firm age and the degree of internationalisation. However, when estimating a Tobit model Barrios et al. (2003) find such a positive effect of firm age on Spanish manufacturing firms’ export-sales ratio. Moreover, McNaughton (2003) shows that firm age is positively associated with the number of foreign destination countries to which small Canadian firms export their products. We can conclude that the positive relationship between firm age and the firms' export activities is confirmed by some but some but not by all empirical studies reviewed. In particular, the results of Arnold and Hussinger (2005) suggest that in the case of born globals the hypothesised positive relationship may not be valid.

In order to identify additional variables that can be expected to discriminate between firms with different export intensities, it is helpful to fall back on theories of internationalisation from the field of international management. One of the most influential theories is the internationalisation process model developed by Johanson and Vahlne $(1977,1990)$. As already pointed out above, the process model regards internationalisation as a gradual process in which firms incrementally increase their commitment abroad while undergoing a dynamic learning process. The most important criticism of the internationalisation process model is its quasi-deterministic character (Reid 1983). The argument is that firms can decide on their export activities contingent on market conditions. There is no need to proceed in the incremental way described by the model. Johanson and Vahlne (1990) have themselves already listed three exceptions where firms are likely to deviate from the gradually expanding commitment predicted by their model. Firstly, large firms may have enough resources to take larger steps in their internationalisation process (see above). Secondly, relevant knowledge that reduces uncertainty about a foreign market can be acquired by means other than own experience, for example by employing an internationally experienced manager. Finally, if market conditions in different foreign markets are homogenous, firms may generalise experience gained in one market to make larger internationalisation steps in another. 
The model of Johanson and Vahlne emphasises the role of intangible resources like experience in the internationalisation process. This is also a main topic when discussing the resource-based view (RBV) of a firm (e.g., Penrose 1959, Wernerfelt 1984) and the more recent theories that regard organisational capabilities of firms as determinants of their outcome (e.g., Teece et al. 1997, Madhok 1997). RBV models analyse how resources are accumulated and deployed by firms. A firm is interpreted as an idiosyncratic bundle of assets (physical resources as well as intangible resources like know-how, experience or tacit knowledge). Since physical assets are relatively easily obtained or imitated, a firm differentiates itself from its rivals by the intangible resources it possesses. These determine how efficiently physical assets can be used and are therefore vital to the firm's performance. With respect to the internationalisation process, this means that the costs of an international engagement can be reduced if intangible resources lead to a more efficient use of the firm's physical resources. Oviatt and McDougall (1994), for example, regard new technology-based firms that internationalise quickly as firms with an intangible, knowledge-based competitive advantage. This perspective is consistent with the resource-based view of the firm. ${ }^{7}$

The most important way how firms can generate firm-specific intangible assets is to carry out intense in-house R\&D activities. The positive relationship between a firm's R\&D activities and its export intensity is confirmed by the related econometric literature. Bürgel et al. (2004) proved that R\&D intensity positively affects the export-sales ratio of those German and UK-based technologyoriented firms that participated in the first survey this paper is based on. Further, the regression results showed that a higher degree of innovativeness incorporated into the firm's best-selling product increases the observed export intensity (see section 5 on how the degree of innovativeness is operationalised). Wakelin (1997), estimating a truncated regression model using a data set of exporting UK manufacturing firms, found that firm-specific R\&D intensity boosts a firm's exportsales ratio. A positive correlation between a firm's R\&D intensity and its degree of internationalisation could also be confirmed by Dhanaraj and Beamish (2003) for a sample of US-based and Canadian exporters and by Barrios et al. (2003) for a sample of Spanish firms. ${ }^{8}$ Similarly, examining a sample of German manufacturing firms from Lower Saxony, Wagner (2001) obtained positively significant coefficients for three dummy variables indicating different levels of R\&D intensity (compared with firms without any R\&D activities). Further, the firms in Wagner's sample

7 The reasoning of RBV models that firm-specific assets determine the export behaviour of firms is similar to the role of ownership advantages in Dunning's OLI (ownership, location, internalisation) framework, also called the “eclectic paradigm” (Dunning 1993). According to Dunning himself, the eclectic paradigm intends to explain "what are" rather than, in the normative sense, "what should be" a firm’s international business activities.

8 Barrios et al. (2003) further found evidence of positive R\&D spillovers on firms’ export-sales ratios. 
exhibited a higher export intensity if they had registered at least one patent or if they had introduced at least one new product. These relationships are independent of the econometric method applied (OLS, Tobit, Beta regression, GLM regression [cf. Wagner 2001]). Thus, it could be regarded as an econometrically proven fact that firms that possess intangible assets, primarily created by intense $R \& D$ activities, can realise higher export-sales ratios.

In contrast to theoretical approaches that concentrate on firm-specific resources, the transaction cost theory regards a firm as a governance structure (Williamson 1985). The unit of analysis is not the decision-maker itself, but the individual transaction. The transaction cost theory is applied to the analysis of various dimensions of individual firms' export activities, among them the decision whether or not to enter the international market or the choice of the optimal foreign sales mode. Verwaal and Donkers (2002) provided a transaction cost analysis of the relationship between firm size and export intensity. They found that transaction costs have a moderating effect on the exportsize relationship. The transaction costs of selling a firm's products or services strongly depend on product-specific characteristics. Product customisation, for instance, usually requires considerable seller-buyer interactions leading to higher costs of the individual transaction (cf. Stump et al. 2002). The latter argument is in particular true if the firm's products and services are sold abroad and technological requirements, standards, and approval procedures vary substantially across the firm’s foreign destination countries.

This paper's econometric model will include both measures of firm size and firm age and variables that approximate a firm's intangible and transaction-specific assets. The empirical results will show whether their is still an individual effect of size and age on the degree of internationalisation if we control for firm-specific and transaction-specific assets derived from the literature of international management.

\section{The Data}

This paper examines a sample of technology-based firms in Germany and the UK. Technologyoriented firms are identified using the definition of high-technology manufacturing sectors in the UK established by Butchart (1987). He provided a definition based firstly on the ratio of R\&D expenditures to sales and secondly on the share of employees working in R\&D. Using this definition, Butchart identified nineteen UK 1987 SIC codes, which were translated into the NACE Rev. 1 code and are listed in detail in Table 7 of this paper's appendix. Table 7 defines four aggregated manufacturing sectors and augments Butchart's list with a number of selected service sectors (cf. Bürgel et al. 2004). 
The data for this paper's empirical analysis result from two surveys simultaneously carried out in Germany and the UK. The source data set originates from Dun \& Bradstreet in the UK and Creditreform $^{9}$ in Germany. Using these databases, all firms with at least three employees in 1997 that were operating in one or more high-tech sectors as defined by Butchart (1987) and having been founded as legally independent companies ${ }^{10}$ between 1987 and 1996 were selected. This resulted in a population of 3,562 firms from the UK and 5,045 from Germany. A random sample of 2,000 firms was drawn from each country's population, stratified by size class, sector (manufacturing versus services), and, for Germany, by region (Western and Eastern Germany). The firms were first contacted in winter 1997/1998 via a written questionnaire. The first survey was carried out by the London Business School in the UK and the Centre for European Economic Research (ZEW) in Germany. 362 completed questionnaires returned from the UK along with 232 questionnaires from Germany, resulting in a combined net sample of nearly 600 NTBFs from the two countries. The net sample showed no bias with respect to age, size, or sector when compared with the random sample. A bias with respect to internationalisation behaviour could, however, not be ruled out. ${ }^{11}$

In order to determine development and status of internationalisation of this sample of $600 \mathrm{NTBFs}$, a joint research team from the University of Exeter and the ZEW prepared a new survey in which all previously responding firms were to be contacted a second time. In 2003, the companies from the original sample were an average of 12 years old. Thus, some of them were no longer definable as new technology-based firms. ${ }^{12}$ Considering this notion, we shifted our interest from analysing newly founded firms to a more longitudinal perspective of firm development. To determine the target sample of the second survey, all formerly responding firms that turned out to be mismatches (e.g., non-high-tech firms, non-independent foundations) were first excluded. We then eliminated each German firm labelled in the database of Creditreform as "dead" (due to bankruptcy as well as voluntary firm closure) at the beginning of 2003. In the UK, firms that could be identified as dead by the researchers themselves were also excluded from the target sample. It turned out that about

9 As Germany's largest credit rating agency, Creditreform has the most comprehensive database of German firms at its disposal. Creditreform provides data on German firms to the Centre for European Economic Research (ZEW) for research purposes. Dun \& Bradstreet is the UK equivalent.

10 Subsidiaries, de-mergers, or firms that were founded as a management buy-out (MBO) or buy-in (MBI) were excluded from the analysis.

11 The first survey is described in detail in Bürgel et al. (2004). This report also includes numerous descriptive and econometric analyses of this unique data set.

12 In his influential study, Little (1977) used a definition of NTBFs which includes firms as old as 25 years. In contrast, the first survey this paper is based on considered only firms that were ten years of age or younger at the time it was taken, which is in line with more recent studies of NTBFs (see, e.g., Storey and Tether 1996). 
$25 \%$ of the firms had already dissolved. As a result, we produced and subsequently contacted a final target sample of 188 German and 250 UK-based formerly responding firms.

The second survey was conducted in 2003 via computer-aided telephone interviews (CATI). The research team decided on a telephone survey because, due to the limited number of formerly responding firms in the target sample, the assurance of a relatively high response rate and thereby a sufficiently high number of observations was necessary to obtaining reliable econometric results. Fortunately, in both the UK and Germany, the response rate exceeded 50\%, giving us a pool of 244 completed interviews. After performing several consistency checks, 217 companies were retained in the data set for econometric analyses.

\section{Descriptive Analysis}

On average, 26 employees worked in the sampled firms in 2003. Applying a t-test proves that the number of employees of exporting firms significantly exceeds the number of employees of firms with only domestic sales both in Germany and the UK. Investment in R\&D is of major concern to technology-oriented firms. In 2003, the firms in our sample spent on average $12.8 \%$ of their total sales on R\&D. Similar to firm size, the mean R\&D intensity of firms with international sales is significantly higher compared with the mean of non-exporting firms. Interestingly, this significant difference with respect to the firm's R\&D activities can only be observed in 2003. In 1997, i.e., at the time of the first survey, no significant difference in the mean R\&D intensity could be found. Both exporters and non-exporters spent about $15 \%$ of total sales on R\&D. Obviously, during the period between the two surveys, $R \& D$ activities became a distinctive characteristic by which an internationally oriented firm discriminates from its domestic oriented competitors.

Table 1: Firms with International Sales by High-Tech Sectors (in \%)

\begin{tabular}{l|cc|cc|cc|cc}
\hline \multirow{4}{*}{ Sector } & \multicolumn{4}{|c|}{ Germany } & \multicolumn{4}{c}{ UK } \\
& \multicolumn{2}{|c|}{1997} & \multicolumn{2}{c}{2003} & \multicolumn{2}{c}{1997} & \multicolumn{2}{c}{2003} \\
& No & Yes & No & Yes & No & Yes & No & Yes \\
\hline Software/services & 50.0 & 50.0 & 45.5 & 54.5 & 40.6 & 59.4 & 35.5 & 64.5 \\
ICT-hardware & 20.0 & 80.0 & 20.0 & 80.0 & 0.0 & 100 & 0.0 & 100 \\
Engineering & 15.8 & 84.2 & 10.5 & 89.5 & 20.0 & 80.0 & 13.8 & 86.2 \\
Health/life sciences & 20.0 & 80.0 & 20.0 & 80.0 & 0.0 & 100 & 0.0 & 100 \\
Other high-tech manuf. & 27.3 & 72.7 & 27.3 & 72.7 & 25.7 & 74.3 & 31.4 & 68.6 \\
\hline Total & 31.6 & 68.4 & 28.7 & 71.3 & 23.5 & 76.5 & 22.2 & 77.8 \\
\hline \hline
\end{tabular}

Source: ZEW, University of Exeter, own calculations. 
Table 1 shows the share of firms with and without international sales in 1997 and 2003, respectively, considering only those firms that participated in both surveys. In both countries, more than two-thirds of the responding firms had international sales. Even the majority of firms from the service sector (mainly software firms) turned out to have exports, although the percentage of firms with foreign sales is smaller than in any aggregated high-tech manufacturing sector. In the manufacturing industry, firms that belong to the sectors ICT-hardware, engineering, and health/life sciences export more often than other manufacturing firms. In the UK-based sample, all firms in the sectors ICT-hardware and health/life sciences even had international business activities. However, it should be mentioned that the number of observations in these two sectors is rather small. In Germany, only 5 ICT-hardware firms (15 firms in health/life sciences) answered both surveys; in the UK, 12 ICT-hardware firms (10 in health/life sciences) participated in both surveys. ${ }^{13}$

There was a slight increase in international engagement between 1997 and 2003. The overall share of exporting firms increased from 72\% in 1997 to $74 \%$ in 2003. With the exception of other manufacturing firms in the UK, in all sectors the share of firms with exports in 2003 was at least as high as in 1997. Although there is a high persistence in the individual status of internationalisation ${ }^{14}$, quite a high number of firms changed their internationalisation status, leading to entry and exit over time. Nearly $12 \%$ of German and $8 \%$ of UK-based firms left the foreign market between 1997 and 2003. During the same period, 14\% of German firms and 8\% of firms sited in the UK entered the international market. Thus, German high-tech firms more frequently change their internationalisation status, whereas UK firms show a higher persistence in their export behaviour.

In 1997, the firms in our sample generated an average of $23 \%$ of total sales in the foreign market. In the period between the two surveys, the average export intensity rose by 8 percentage points to a value of $31 \%$ in 2003. It is important to note that these average numbers include not only exporting firms but also companies without international sales. The latter group of firms decided that their optimal volume of exports was zero. Thus, the degree of internationalisation has many limit observations at the value zero (about a quarter of all observations).

Since the percentage of internationally active firms in our sample increased only slightly from 1997 to 2003, the higher average export intensity is merely to a small extent a result of additional

13 In fact, in contrast to the first survey where no sector bias was found, the ICT-hardware sector is underrepresented in the German as well as in the UK-based sample. Conversely, the health/life sciences sector (engineering sector) is overrepresented in the German (UK-based) sample.

14 In order to explain the observed high persistence in firms' export behaviour, Roberts and Tybout (1997) augmented their dynamic model with sunk entry costs. The authors can prove empirically the existence of sunk costs and their relevance for the decision to enter the foreign market based on a sample of Colombian plants of the manufacturing sector, observed between 1981 and 1989 inclusively. 
firms entering into the international market. The rise in the sample's export-sales ratio is mainly caused by the expanding international business activities of continuously exporting firms. The average share of total turnover the sample's exporters generated through foreign sales went up from 33\% in 1997 to $43 \%$ in 2003. Similarly, the percentage of exporting firms in which nondomestic revenues exceeded 50\% of total revenues increased from 26\% in 1997 to $37 \%$ at the time of the second survey. These numbers become even more impressive if we consider that (discounted) sales of firms that had exports in 2003 grew on average by 14.6\% per year from 1997 to 2002. Thus, the annualised growth rates of the firms' volume of exports had to be even higher so that the mean ratio of exports to total sales could increase.

On average, the export intensity of UK firms exceeds that of German firms (see Table 2). The difference is significant according to a conventional t-test. This statement is valid for the pooled sample as well as for the two subsamples of 1997 and 2003. Restricting ourselves to the group of exporting firms, Table 2 shows that the average export intensity of UK-based (German) firms rose from 39\% (24\%) in 1997 to 50\% (33\%) in 2003. In 2003, 51\% of UK exporters generated more

Table 2: Comparison of Mean Degree of Internationalisation Exporters and non-exporters

\begin{tabular}{l|cc|l}
\hline \hline & Germany & UK & $t$-test \\
\hline Pooled sample & 19.8 & 33.5 & $* * *$ \\
1997 & 16.5 & 28.9 & $* * *$ \\
2003 & 23.2 & 38.2 & $* * *$ \\
\hline & West Germany & East Germany & \\
\hline Pooled sample & 23.5 & 12.8 & $* * *$ \\
1997 & 20.7 & 8.3 & $* * *$ \\
2003 & 26.5 & 17.2 & $*$ \\
\hline \hline
\end{tabular}

\section{Exporters only}

\begin{tabular}{l|cc|l}
\hline \hline & Germany & UK & t-test \\
\hline Pooled sample & 28.6 & 44.5 & $* * *$ \\
1997 & 24.2 & 38.8 & $* * *$ \\
2003 & 33.0 & 50.1 & $* * *$ \\
\hline & West Germany & East Germany & \\
\hline Pooled sample & 31.2 & 22.1 & $* *$ \\
1997 & 27.8 & 14.8 & $* *$ \\
2003 & 34.8 & 28.9 & \\
\hline \hline
\end{tabular}

* $10 \%$ level of significance; ** 5\% level of significance; *** $1 \%$ level of significance.

Note: Only firms that participated in both surveys were considered.

Source: ZEW, University of Exeter, own calculations. 
than $50 \%$ of their total revenues abroad. In Germany, for only $17 \%$ was the foreign market, in terms of sales, more important than the home market. Obviously, the export-sales ratio was higher for UK-based exporters than for their German counterparts. This was the case at the time of the first survey and remained valid, although both UK and German firms had, on average, intensified their international engagement. As Bürgel et al. (2004) argued, this might be the case because UK exporters more pro-actively exploit the sales potential of foreign markets or because German firms are less dependent on the international market due to the larger size of their domestic market.

Firms located in Western Germany sell a significantly higher share of their total turnover abroad than firms from the eastern part of Germany. The smaller degree of internationalisation of Eastern German firms in the combined sample of exporters and non-exporters results from the smaller percentage of internationally active Eastern German firms as well as from the lower export intensity of Eastern German exporters. The latter fact is shown by the lower part of Table 2, where the export-sales ratio is calculated for our sample's exporters only. Interestingly, whereas the difference of the average export intensity between exporters from the two parts of Germany amounted to 13 percentage points in 1997, this difference dropped to only 6 percentage points in 2003 and was no longer significant in this year. Obviously, Eastern German firms face an initial drawback that reduces their probability of exporting and their degree of internationalisation during early stages of their international engagement, e.g., because regional spillover effects Western German firms may profit from were absent in Eastern Germany in the first years after German reunification. However, Eastern German exporters were able to overcome this disadvantage in the period leading up to 2003 and reach an export intensity comparable with that of Western German exporters.

The relationship between the degree of internationalisation and firm size is of particular interest. Therefore, Table 3 contains the average export intensities of our sample's firms in different size classes, where size is measured by the number of employees. The export-sales ratios for the subsample of UK firms exhibit the theoretically expected relationship: The export intensity increases with firm size, but firms in the largest class (more than 50 employees) generate a smaller share of their total revenues abroad than firms in the second-largest class (between 21 and 50 employees), probably due to raising costs of coordinating their export activities. The subsample of German firms does not show such an even picture. Nevertheless, firms with up to five employees reach a relatively small degree export intensity compared with larger firms. At the time of the first survey, German firms with more than 50 employees generated on average 53\% of their total revenues in the foreign market. However, this impressively high figure is based on only four observations of which all had international sales. In 2003 there were eleven firms in the German subsample that had more than 50 employees. Some of the firms that grew in the period between the two surveys, 
Table 3: Degree of Internationalisation, by Size Classes

\begin{tabular}{l|c|c|c|c}
\hline \hline \multirow{2}{*}{ Number of employees } & \multicolumn{2}{|c|}{ Germany } & \multicolumn{2}{c}{ UK } \\
\hline 5 or less & 1997 & 2003 & 1997 & 2003 \\
$6-10$ & 9.1 & 13.8 & 22.1 & 24.4 \\
$11-20$ & 14.6 & 11.9 & 22.9 & 27.6 \\
$21-50$ & 17.4 & 30.1 & 33.3 & 42.6 \\
more than 50 & 16.3 & 25.6 & 36.3 & 49.4 \\
\hline Total & 53.0 & 31.1 & 29.8 & 44.1 \\
\hline \hline
\end{tabular}

Note: Combined sample of exporters and non-exporters was used.

Only firms that participated in both surveys were considered.

Source: ZEW, University of Exeter, own calculations.

exceeding the threshold value of 50 employees, did not export in 2003, making the average degree of internationalisation significantly smaller when compared with the respective value in 1997.

The mean degree of internationalisation in various age classes is shown in Table 4 (combined sample of exporting and non-exporting firms). With the exception of UK firms in the oldest category in 2003, the table confirms that the export-sales ratio increases with firm age. The positive relationship between firm age and the firms' export-sales ratio also applies to the subsample of exporting firms (not reported here). ${ }^{15}$ Thus, the higher degree of internationalisation of older firms is not only a result of the higher percentage of exporters among these firms (share of exporting firms in the youngest category in 1997: 61\%, compared with 75\% in the other two categories).

Table 4: Degree of Internationalisation, by Age Classes

\begin{tabular}{l|c|c|l|c|c}
\hline \multicolumn{2}{|c|}{$\mathbf{1 9 9 7}$} & \multicolumn{2}{|c}{$\mathbf{2 0 0 3}$} \\
Age (in years) & Germany & UK & Age (in years) & Germany & UK \\
\hline 4 or younger & 12.2 & 22.9 & 10 or younger & 18.4 & 33.3 \\
$5-7$ & 18.0 & 27.6 & $11-13$ & 25.1 & 39.1 \\
8 or older & 20.6 & 31.5 & 14 or older & 27.2 & 38.6 \\
\hline Total & 16.5 & 28.8 & Total & 23.2 & 38.2 \\
\hline \hline
\end{tabular}

Note: Combined sample of exporters and non-exporters was used.

Only firms that participated in both surveys were considered.

Source: ZEW, University of Exeter, own calculations.

15 As in the case of the combined sample of exporting and non-exporting firms, there is one exception from this rule: In 2003, German exporters in the middle category exhibit a smaller export-sales ratio than German exporters in the youngest category. On the other hand, the average export intensity of UK-based exporters in the oldest category in 2003 exceeds that of UK exporters in the middle category. 


\section{Econometric Implementation}

In the related literature, the degree of internationalisation is often examined econometrically using two-step approaches (see, among others, Wakelin 1997): In the first step, the firm decides whether to internationalise or not, and in the second step the optimal volume of exports is selected. Wagner (2001), however, argued that foreign market entry and the profit-maximising volume of exports are chosen simultaneously. Thus, the firm's decision-making process has to be modelled as a onestep approach. Following Wagner (2001, 2003), I apply the fractional logit model developed by Papke and Wooldridge (1996) for estimating the export intensity of the firms in our sample. Let $Y_{i}$ denote the export-sales ratio of firm $i$, where $0 \leq Y_{i} \leq 1$. Papke and Wooldridge assumed that, for all $i$, the expected value of $Y_{i}$ conditional on a vector of explanatory variables $X_{i}$ is given by

$$
E\left(Y_{i} \mid X_{i}\right)=F\left(X_{i} \beta\right)
$$

with $0<F\left(X_{i} \beta\right)<1$ for all $X_{i} \beta \in \mathbb{R}$, ensuring that the predicted values of $Y_{i}$ lie in the interval $(0,1)$. Nevertheless, equation (2) is defined even if $Y_{i}$ takes the limit observations zero or one. The function $F(\cdot)$ is assumed to be the cumulative distribution function (cdf) of the logistic distribution: 16

$$
F\left(X_{i} \beta\right) \equiv \Lambda\left(X_{i} \beta\right) \equiv \frac{\exp \left(X_{i} \beta\right)}{1+\exp \left(X_{i} \beta\right)}
$$

Papke and Wooldridge proposed a quasi-maximum likelihood estimator (QMLE) of $\beta$, following Gourieroux et al. (1984) and McCullagh and Nelder (1989).The Bernoulli log-likelihood function is maximised using the generalised linear models (GLM) framework developed by McCullagh and Nelder (1989). Following Papke and Wooldridge, I further apply a robust estimate of the asymptotic variance of $\hat{\beta}$.

The vector of explanatory variables may contain both firm-specific variables and variables exogenous to the firm. According to the trade theories (cf. Baldwin and Krugman 1989, Krugman 1989), exchange rates are supposed to play a crucial role in influencing a firm's decision to export. To determine the effect of an exchange rate movement, I constructed weighted real exchange rate indices for the euro (Deutsche Mark) and the British pound for each of the five high-tech sectors. ${ }^{17}$

16 However, Papke and Wooldridge (1996) emphasised that $F(\cdot)$ may not necessarily be a cdf.

17 Nominal exchange rates were taken from the historical exchange rate database of Oanda Corp., available at http://www.oanda.com. Consumer price indices used to calculate real exchange rates were taken from Global Economic Data of EconStats, available at http://www.econstats.com. 
The weights are defined by the share of exports of each respective industry to that industry's ten most important export countries as revealed by the 1997 survey, computed separately for German and UK firms. Calculating exchange rate indices in this way, we are essentially able to estimate the reaction of (potential) exporters to changes in prices on the industry's most important foreign markets (cf. Bernard and Jensen 2004).

The set of firm-specific variables will include the logarithm of firm size (measured by the number of employees), its squared value, and the logarithm of firm age (measured in years). These are the key variables of this study's empirical analysis. In addition, the vector of independent variables will contain variables that were derived from the literature of international management. Johanson and Vahlne (1990) argued that relevant knowledge that reduces uncertainty about a foreign market can be acquired by means other than own experience, for example by employing an internationally experienced manager. The empirical model will therefore include two dummy variables indicating whether, according to the interviewees, the firm's managers had work experience abroad or were educated in a foreign country before joining the company.

The resource-based view of the firm emphasises the role of intangible resources which may be generated via intense in-house R\&D activities. A firm’s R\&D activities are characterised by two dummy variables that indicate whether a firm is carrying out $R \& D$ on a permanent basis or occasionally. Firms without any R\&D activities are used as the base category. Moreover, the innovativeness of a firm's best-selling product is determined by two dummy variables revealing whether the product incorporates novel technology that had been developed in-house specifically for this product or whether it merely incorporates novel technology that had been developed elsewhere by other companies. A second key element of the firms' intangible assets consist in their human capital. The international experience of firm managers can be regarded as such an intangible asset (cf. the previous paragraph on how firm managers' international experience is operationalised). However, not only previous (international) experience but also and in the first line integral capabilities and skills possessed by members of the management team are likely to increase a firm's ability to attain a higher export-sales ratio. Therefore, the firms' representatives were asked to indicate on a five point Likert scale whether they experience a shortage of skills in different areas, among them sales, distribution, production, and R\&D. The econometric model will include two dummy variables taking the value 1, if a firm's managers experience a "serious" (4) or a "very serious shortage” (5) in sales/distribution and production/R\&D, respectively.

High transaction costs may act as a constrain to realise a high export intensity. High customisation requirements involve close contacts to customers, which may induce high transaction costs prior to 
selling the firm's product or service. Similarly, regular maintenance and the necessity of frequent upgrades may lead to high transaction costs after the product has been sold. The questionnaires used in both surveys measure the degree of customisation and the requirement of regular maintenance on a five point Likert scale ranging from 1 "unimportant” to 5 "very important." For the econometric estimations, two dummy variables will be used taking the value 1 , if the firm has classified the requirements of customisation and regular maintenance, respectively, as "important" (4) or "very important" (5). Moreover, a dummy variable indicating whether the firm's best selling product is sold directly to end-users will be included in the econometric model. Selling a product or service to a large number of far distant end-users may lead to higher communication and distribution costs, restricting the extent of a firm’s international business activities.

To control for regional and sector-specific peculiarities, I will add two dummy variables for firms located in Western and Eastern Germany respectively, using UK-based firms as the base category, and two industry dummies for engineering sector and other high-tech manufacturing industries (including the relatively small sectors of ICT-hardware and health/life sciences). Thus, software and service firms will be the base category. Finally, I will include a year dummy taking the value 1 if the observation falls in the second period, i.e., in 2003.

\section{Empirical Results}

The estimation results of the fractional logit models are presented in Table 5 (pooled sample) and Table 6 (subsamples of 1997 and 2003). ${ }^{18}$ It is immediately apparent that the results of the pooled regression are very similar to those of the two separated regressions. Thus, both in 1997 and 2003 the degree of internationalisation is determined by essentially the same independent variables. There are no variables that lose their influence in the period between the two surveys and no additional variables that affect the export intensity only during a later stage of the firms' international engagement - at least no variables that were observed. However, regarding the results of the pooled regression we find that the time dummy indicating all observations of the second survey is positively significant. Setting all other variables to their mean, a discrete change of this time dummy variable from 0 to 1 (i.e., a hypothetical switch from 1997 to 2003) increases the exportsales ratio by just under 13 percentage points. ${ }^{19}$ Thus, there is a shift of the endogenous variable in

18 The model was estimated using the glm command of the software package STATA, version 8.2 SE. For a detailed discussion of estimating generalised linear models with STATA see Hardin and Hilbe (2001).

19 Note that the tables show the estimated coefficients and not marginal effects or discrete changes of the included dummy variables. 


\begin{tabular}{|c|c|c|c|}
\hline & \multicolumn{3}{|c|}{$\begin{array}{c}\text { Number of observations }=356 \\
\qquad \begin{array}{c}\mathrm{LL}=-151.852 \\
\chi^{2}(20)=146.63 \\
\text { Prob }>\chi^{2}(20)=0.000 \\
\mathrm{R}^{2}=0.279\end{array}\end{array}$} \\
\hline & Coeff. & $\begin{array}{c}\text { Robust } \\
\text { stand. errol }\end{array}$ & \\
\hline Time dummy (2003=1) & 0.674 & 0.272 & $* *$ \\
\hline Industry real exchange rate & 0.005 & 0.030 & \\
\hline West Germany & -0.460 & 0.187 & $* *$ \\
\hline East Germany & -1.097 & 0.239 & $* * *$ \\
\hline Engineering & 0.903 & 0.229 & $* * *$ \\
\hline Other manufacturing industries & 0.551 & 0.199 & $* * *$ \\
\hline Log (number of employees) & 0.474 & 0.417 & \\
\hline Log (number of employees) ${ }^{2}$ & -0.036 & 0.065 & \\
\hline Log (age) & -0.059 & 0.304 & \\
\hline Permanent R\&D activities & 0.936 & 0.308 & $* * *$ \\
\hline Occasional R\&D activities & 0.685 & 0.330 & $* *$ \\
\hline Novel self-developed technology & -0.169 & 0.168 & \\
\hline Novel techn., developed elsewhere & 0.426 & 0.213 & $* *$ \\
\hline Work experience abroad & 0.573 & 0.168 & $* * *$ \\
\hline Education abroad & 0.371 & 0.202 & $*$ \\
\hline \multicolumn{4}{|l|}{ Shortage in competencies } \\
\hline Sales/distribution & -0.255 & 0.173 & \\
\hline Production/R\&D & 0.082 & 0.188 & \\
\hline Intense product customisation & -0.506 & 0.165 & $* * *$ \\
\hline Regular maintenance and upgrades & -0.156 & 0.177 & \\
\hline Consumer good & 0.062 & 0.175 & \\
\hline Constant & -3.625 & 3.124 & \\
\hline
\end{tabular}

* $10 \%$ level of significance; ** $5 \%$ level of significance; *** $1 \%$ level of significance.

Base category: UK-based software firm without R\&D activities.

Source: own estimation.

the period between the two surveys that is not covered by the remaining set of exogenous variables. In other words, our model is able to explain varying export intensities at a given point in time reasonably well, but it is unsuitable for representing the expansion of the firms' international business activities over time. Observing the firms in our sample over a longer time period and thus building up a panel data set may be a way to discover determinants of our firms' international expansion. For example, according to theory, firms decide simultaneously on foreign market entry and their preferred volume of exports. However, due to limited resources exporters are probably not able to realise their optimal volume of exports immediately after foreign market entry. Thus, firms may start their international engagement with a suboptimal volume of exports, gradually 
increasing their exports until the optimum volume is reached. Alternatively, the increasing exportsales ratio can be interpreted as mirroring the rising globalisation on high-tech markets. In this case, the firms in our sample simply followed a global trend that cannot be explained by the firmspecific variables in our data set.

The industry real exchange rate does not influence the degree of internationalisation. This is probably due to the small variance of this variable. ${ }^{20}$ The insignificant effect of the industry real exchange rate may also be traced back to the fact that the majority of the firms' most important (in terms of sales) foreign destination countries belong to the European Union. Since the introduction of the euro, changes in exchange rates are therefore of minor importance - at least for the German firms in our sample. In accordance with the descriptive statistics, the export intensity of German firms is significantly smaller than that of UK-based firms. Whereas firms from Eastern Germany are less likely to enter the foreign market and show a significantly lower export-sales ratio than UK firms, the probability of internationalisation of Western German firms is comparable with that of UK-based firms. Nevertheless, the degree of internationalisation of Western German firms is smaller than the respective value of their British counterparts. The two dummy variables indicating the two aggregated manufacturing sectors are both positively significant: Manufacturing firms generate a higher share of their total sales abroad than software and service firms. For 2003 the dummy variable of the sector of other manufacturing firms is not significant, implying that at the time of the second survey there is no difference between this sector and software and service firms. This corresponds to the findings of the descriptive analysis.

The relationship between firm size and the degree of internationalisation is of major interest in the related literature. Most studies cited above found that firm size positively influences the exportsales ratio, but that this relationship is non-linear and decreases with size. The estimated coefficients of the fractional logit models do indeed show the expected signs, i.e., a positive sign for (the logarithm of) the number of employees and a negative one for its squared value. However, in contrast to other studies these effects are not significant. Figure 1 displays the predicted degree of internationalisation in dependence of the number of employees, with all other variables set to their mean. Each of the three graphs reveals the same picture: The predicted export intensity increases with firm size, but the marginal effect (i.e., the slope of the solid lines in Figure 1) declines as the

20 The firms in the sample are observed only twice with a six year interval between the two surveys. The weighted exchange rate indices, thus, take only two different values for each industry in Germany and the UK, respectively. Moreover, the calculated indices show only minor movements in the weighted real exchange rates of the euro (Deutsche Mark) and the pound from 1997 to 2003. Although the nominal exchange rate of the euro and the pound to the most important foreign currency, the US dollar, did indeed changed significantly during the period from 1997 to 2003, the average rate in 1997 was nearly the same as the average rate in 2003. 
Table 6: Fractional Logit Estimation Results: Subsamples 1997 and 2003

\begin{tabular}{|c|c|c|c|c|c|c|}
\hline & \multicolumn{3}{|c|}{1997} & \multicolumn{3}{|c|}{2003} \\
\hline & \multicolumn{3}{|c|}{$\begin{array}{c}\text { Number of observations }=173 \\
\qquad \mathrm{LL}=-70.615 \\
\chi^{2}(18)=66.01 \\
\text { Prob }>\chi^{2}(18)=0.000 \\
\mathrm{R}^{2}=0.229\end{array}$} & \multicolumn{3}{|c|}{$\begin{array}{c}\text { Number of observations }=183 \\
\qquad \begin{array}{c}\mathrm{L} L=-80.071 \\
\chi^{2}(18)=93.32 \\
\text { Prob }>\chi^{2}(18)=0.000 \\
\mathrm{R}^{2}=0.322\end{array}\end{array}$} \\
\hline & \multicolumn{3}{|c|}{$\begin{array}{c}\text { Robust } \\
\text { stand. error }\end{array}$} & \multicolumn{3}{|c|}{$\begin{array}{c}\text { Robust } \\
\text { stand. error }\end{array}$} \\
\hline West Germany & -0.269 & 0.297 & & -0.690 & 0.287 & $* *$ \\
\hline East Germany & -1.269 & 0.402 & $* * *$ & -1.041 & 0.286 & $* * *$ \\
\hline Engineering & 0.861 & 0.357 & $* *$ & 0.879 & 0.314 & $* * *$ \\
\hline Other manufacturing industries & 0.671 & 0.313 & $* *$ & 0.350 & 0.271 & \\
\hline Log (number of employees) & 0.582 & 0.667 & & 0.499 & 0.542 & \\
\hline Log (number of employees) ${ }^{2}$ & -0.056 & 0.111 & & -0.038 & 0.082 & \\
\hline Log (age) & -0.034 & 0.372 & & 0.002 & 0.505 & \\
\hline Permanent R\&D activities & 0.896 & 0.471 & $*$ & 1.053 & 0.386 & $* * *$ \\
\hline Occasional R\&D activities & 0.892 & 0.489 & * & 0.387 & 0.446 & \\
\hline Novel self-developed technology & -0.098 & 0.262 & & -0.338 & 0.239 & \\
\hline Novel techn., developed elsewhere & 0.444 & 0.284 & & 0.369 & 0.347 & \\
\hline Working experience abroad & 0.630 & 0.276 & $* *$ & 0.552 & 0.224 & $* *$ \\
\hline Education abroad & 0.219 & 0.309 & & 0.398 & 0.259 & \\
\hline \multicolumn{7}{|l|}{ Shortage in competencies } \\
\hline Sales/distribution & -0.126 & 0.297 & & -0.335 & 0.228 & \\
\hline Production/R\&D & 0.049 & 0.301 & & 0.052 & 0.265 & \\
\hline Intense product customisation & -0.470 & 0.239 & $* *$ & -0.616 & 0.229 & $* * *$ \\
\hline Regular maintenance and upgrades & -0.180 & 0.291 & & -0.148 & 0.225 & \\
\hline Consumer good & 0.040 & 0.233 & & 0.280 & 0.289 & \\
\hline Constant & -3.498 & 1.382 & $* *$ & -2.413 & 1.595 & \\
\hline
\end{tabular}

* $10 \%$ level of significance; ** $5 \%$ level of significance; *** $1 \%$ level of significance.

Base category: UK-based software firm without R\&D activities.

Source: own estimation.

number of employees rises. The confidence interval points out that the uncertainty associated with predicting the export-sales ratio is larger for very small firms (read: less than 10 employees) than for medium-sized firms. ${ }^{21}$ In the group of very small firms, the share of firms without any international sales is comparably high. At the same time, there are some firms that generate the majority of their total sales in the foreign market, in spite of having less than 10 employees. Thus, the variance and the associated confidence intervals of the (predicted) degree of internationalisation

21 The confidence intervals of the predicted export-sales ratio for firms with more than 50 employees are very large. In particular in 1997, very few firms in our sample exceeded the threshold of 50 employees. For large firms, Figure 1 constitutes an out-of-sample forecast, impeding a prediction of large firms' export intensities. 
are relatively large for the group of very small firms. Some small firms in our sample are able to overcome the barriers to entry into the foreign market since they possess intangible assets, e.g., generated by R\&D activities (see the discussion below). We can conclude that firm size is not necessary to attain a high export-sales ratio. This finding supports the conclusion of Wagner (2003), who emphasised that it is not size per se that makes a successful exporter.

Firm age, the second key variable of this study's econometric analysis, was hypothesised to have a positive effect on the firms' degree of internationalisation (Johanson and Vahlne 1990, Kaiser and Kongsted 2004). However, (the logarithm of) firm age reveals its insignificance in our econometric model. Interestingly, the coefficient of firm age is not significant, even if the regression is based on the subsample of 1997. Probably, some of the firms in our sample (e.g., the group of "born globals") pro-actively exploit opportunities on the foreign market, reaching their optimal export intensity at an early stage of their life cycle. These firms may overcome uncertainty present in the international market or other barriers to entry by, for example, employing internationally experienced managers (see below). Thus, youth is likewise not necessarily an obstacle to realising a high export intensity.

The result that neither firm size nor firm age has an individual effect on the export-sales ratio of young technology-oriented firms in Germany and the UK leads to the question which firm-specific variables are instead able to explain the various export intensities of our sampled firms. Our estimation results show that $R \& D$ activities through which firms generate intangible assets in order to distinguish themselves from their rivals positively affect the degree of internationalisation. Whether a firm carries out permanent or only occasional R\&D activities is not decisive. Obviously, it is sufficient when a firm conducts any R\&D activities at all - at least in 1997. At the time of the second survey, the dummy variable indicating occasional $R \& D$ activities is no longer significant. This variable likely has no more discriminatory power in 2003 since the share of firms in our sample with occasional R\&D activities reduced significantly from 1997 to 2003. Firms tended to decide to carry out either permanent R\&D activities or no R\&D activities at all. Moreover, the share of total sales that firms with occasional $R \& D$ activities spent on $R \& D$ also decreased: Whereas in 1997 the mean R\&D intensity of these firms amounted to $10.3 \%$, this value fell to $5.8 \%$ in 2003. As a result, there is no significant difference between firms with occasional R\&D activities and companies that refrain from researching with respect to their degree of internationalisation. The remaining two variables that are intended to reflect the innovativeness of a firm's product, the two dummy variables indicating the firms' adoption of novel technology, are both not significant in the fractional logit estimations based on the two subsamples of 1997 and 2003. However, in the pooled regression the dummy reflecting the use of novel technology that was 
developed by other companies is positively significant, whereas the dummy variable indicating the adoption of self-developed technology has no effect on the export intensity. The impact of the latter variable is probably already covered by the two dummy variables indicating the extent of a firm’s R\&D activities. However, a firm can also create intangible assets by buying novel technology from other companies and incorporating this technology into its production process, i.e., without conducting own R\&D activities.

A firm's engagement in the foreign market is facilitated by the international experience of the members of its management team. Work experience abroad of at least one firm manager increases the export intensity. The results of the fractional logit models reveal that the respective dummy variable is positively significant using data from the pooled sample and the two subsamples from 1997 and 2003. If a firm manager is familiar with foreign business practices and market conditions due to experience acquired while working in a foreign country, the company is able to attain a higher export-sales ratio. The dummy variable indicating whether at least one manager was educated abroad before joining the company is only significant in the regression using pooled data and at the $10 \%$ level. Estimating the two subsamples, this dummy remains insignificant at any conventional level. In order to realise a high export-sales ratio, it is obviously important that firm manager are familiar with foreign business practices and market conditions. Such familiarity can be better acquired by working in a foreign country rather than studying abroad. The other two dummy variables, reflecting firm managers' capabilities by indicating experienced shortages in sales/distribution and production/R\&D, are neither individually nor jointly significant (Wald test of joint significance, based on the pooled regression: $\chi^{2}(2)=2.30$, [Prob $\left.>\chi^{2}\right]=0.317$ ). If a firm manager experiences shortages in a particular area of management, this will probably have the same impact on foreign as well as domestic sales, leaving the export-sales ratio unaffected.

Intense customisation is the only transaction-specific variable that affects the extent of our firms' export activities. Neither the necessity of regular maintenance nor distinguishing to whom a firm's best-selling product is sold (directly to end-users or to other companies) are able to discriminate between the firms in our sample. Product customisation is a barrier to entry into the foreign market. It impedes realising economies of scale and, as a consequence, restricts the volume of exports. If a product requires client-specific customisation, the firm will often export its product to only a limited number of foreign customers, realising a degree of internationalisation that makes its international business activities profitable but that is smaller than the export intensity of other firms. The lower export intensity may nevertheless be optimal for the firm, given its additional transaction costs caused by the requirement of intense customisation. 
In order to test the validity of the model, I applied a specification test derived by Pregibon (1979). The concept behind the test is as follows: If the model is correctly specified, then in an auxiliary GLM regression of the degree of internationalisation on the prediction and the prediction squared, the prediction squared should not have any explanatory power. Thus, the alternative model is:

$$
E\left(Y_{i} \mid X_{i}\right)=F\left(X_{i} \beta+\gamma\left(X_{i} \beta\right)^{2}\right)
$$

where, again, $F(\cdot)$ is the logistic function $\Lambda(\cdot)$. Under the null hypothesis $H_{0}: \gamma=0$, the model is correctly specified, i.e., the test statistic is the conventional t-statistic of the quadratic term in the auxiliary GLM regression. The specification test based on the pooled regression cannot reject the null hypothesis (t-statistic: -0.26). The quadratic term is likewise insignificant in the two auxiliary regressions that are related to the two subsamples (1997: t-statistic: 0.09; 2003: t-statistic: -0.53 ). Thus, Pregibon’s specification test reveals no problems with the chosen specification.

The fractional logit model fits reasonably well with the data. As Papke and Wooldridge (1996) pointed out, the simple $\mathrm{R}^{2}$, conventionally defined as 1 - SSR/SST (with SSR = sum of squared residuals and SST = total sum of squares), is the most appropriate goodness-of-fit measure, since only the conditional expectation of the degree of internationalisation is modelled, with other features of the conditional distribution left unspecified (see Papke and Wooldridge 1996, p. 629).

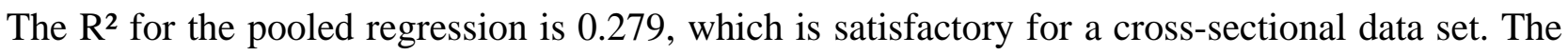
respective values for the regressions based on the two subsamples are of similar size (1997: 0.229; 2003: 0.322).

\section{Conclusion}

This paper examines the export-sales ratio of newly founded technology-oriented firms in Germany and the UK. While the participation rate in the international market increased only slightly from 1997 to 2003, the group of exporters in our sample expanded their international business activities significantly, raising the average degree of internationalisation from 33\% in 1997 to $43 \%$ in 2003. At the time of the second survey, $37 \%$ of the exporters even generated more than $50 \%$ of their total revenues abroad. These are indeed impressive findings, indicating that the majority of young high-tech firms in Germany and the UK were able to establish themselves in the international market. Unfortunately, the econometric model used in this paper cannot explain the shift in export intensity in the period between the two surveys. Nevertheless, our model describes varying degrees of internationalisation at a given point in time reasonably well. 
Essentially, firms that generate intangible assets through (permanent) $R \& D$ activities generate a higher share of their total sales abroad. Similarly, if a firm employs internationally experienced managers it will be able to increase its export-sales ratio. On the other hand, the optimal volume of exports is negatively influenced by the requirement of intense product customisation.

The key result of this paper is that neither youth nor smallness are necessarily an obstacle to realising a high export intensity. Firms that internationalise shortly after their inception ("born globals”) pro-actively exploit the foreign market and reach a relatively high degree of internationalisation at an early stage of their international engagement. Similarly, even firms that have less than 10 employees are able to attain a high export-sales ratio. However, this requires that the firms possess firm-specific assets in order to overcome barriers to entry into the foreign market. As our analysis shows, these firm-specific assets may be acquired via conducting own $R \& D$ activities, buying novel technology from other companies, or by employing internationally experienced managers. It is important to note, however, that there is a considerable heterogeneity within the group of young and/or small firms. Figure 1 reveals that for very small firms a prediction of (the conditional mean of) the degree of internationalisation is associated with high uncertainty (i.e., large confidence intervals). This implies that apart from those very small exporters that pro-actively exploit the foreign market, there are firms that gradually increase their international engagement, attaining a high export-sales ratio only after they raised their number of employees. Thus, for the latter group of firms the export-sales ratio may be causally linked with the firms' size. Nevertheless, for a large proportion of the firms in our sample, size and age are not prerequisites for realising a high degree of internationalisation, which leads to insignificant coefficients in the regression equations. If young and small technology-oriented firms in Germany and the UK acquire the necessary firmspecific resources, they will have the best qualifications for becoming successful exporters, or, as Simon (1996) called them, "hidden champions.” 


\section{References}

Arnold, J. M., and K. Hussinger (2005), Export Behavior and Firm Productivity in German Manufacturing, Review of World Economics, 141 (2), 219-243.

Baldwin, R. E., and P. R. Krugman (1989), Persistent Trade Effects of Large Exchange Rate Shocks, Quarterly Journal of Economics, 104 (4), 635-654.

Barrios, S., H. Görg, and E. Strobl (2003), Explaining Firms’ Export Behaviour: R\&D, Spillovers and the Destination Market, Oxford Bulletin of Economics \& Statistics, 65 (4), 475-496.

Bernard, A. B., and J. B. Jensen (2004), Why Some Firms Export, Review of Economics and Statistics, 86 (2), 561-569.

Bernard, A. B., and J. Wagner (2001), Export Entry and Exit by German Firms, Review of World Economics, 137 (1), 105-123.

Bilkey, W. J., and G. Tesar (1977), The Export Behavior of Small-Sized Wisconsin Manufacturing Firms, Journal of International Business Studies, 8 (1), 93-98.

Bürgel, O., A. Fier, G. Licht, and G. C. Murray (2004), The Internationalisation of Young HighTech Firms, ZEW Economic Studies, 22, Heidelberg, New York.

Butchart, R. (1987), A New UK Definition of High-Technology Industries, Economic Trends, 400, 82-88.

Dhanaraj, C., and P. W. Beamish (2003), A Resource-Based Approach to the Study of Export Performance, Journal of Small Business Management, 41 (3), 242-261.

Dunning, J. H. (1993), Multinational Enterprises and the Global Economy, Wokingham: Addison-Wesley.

European Commission (2002), High-Tech SMEs in Europe, in: Observatory of European SMEs, No. 6, Luxembourg.

Geringer, J. M., P. W. Beamish, and R. C. daCosta (1989), Diversification Strategy and Internationalization: Implications for MNE Performance, Strategic Management Journal, 10 (2), 109-119.

Gouriéroux, Ch., A. Monfort, and A. Trognon (1984), Pseudo-Maximum Likelihood Methods: Theory, Econometrica, 52 (3), 681-700.

Greene, W. H. (2000), Econometric Analysis, fourth edition, New York: Prentice-Hall.

Hardin, J. W., and J. Hilbe (2001), Generalized Linear Models and Extensions, College Station, Texas: Stata Press.

Johanson, J., and J.-E. Vahlne (1977), The Internationalization Process of the Firm - a Model of Knowledge Development and Increasing Market Commitments, Journal of International Business Studies, 8 (1), 23-32.

Johanson, J., and J.-E. Vahlne (1990), The Mechanism of Internationalisation, International Marketing Review, 7 (4), 11-24.

Kaiser, U., and H. C. Kongsted (2004), True Versus Spurious State Dependence in Firm Performance: The Case of West German Exports, Centre for Economic and Business Research, Discussion Paper 2004-07, Copenhagen.

Krugman, P. R. (1989), Exchange-Rate Instability, Cambridge, MA: MIT Press. 
Lindqvist, M. (1991), Infant Multinationals: The Internationalization of Young, Technology-Based Swedish Firms, Stockholm School of Economics, Institute of International Business, Stockholm.

Little, A. D. (1977), New Technology-Based Firms in the United Kingdom and the Federal Republic of Germany, Anglo-German Foundation for the Study of Industrial Society, London, Bonn.

Madhok, A. (1997), Cost, Value and Foreign Market Entry Mode: The Transaction and the Firm, Strategic Management Journal, 18, 39-61.

Mañez, J. A., M. E. Rochina, and J. A. Sanchis (2004), The Decision to Export: A Panel Data Analysis for Spanish Manufacturing, Applied Economics Letters, 11 (11), 669-673.

McCullagh, P., and J. A. Nelder (1989), Generalized Linear Models, second edition, New York: Chapman and Hall.

McDougall, P. P., S. Shane, and B. M. Oviatt (1994), Explaining the Formation of International New Ventures: The Limits of International Business Research, Journal of Business Venturing, 9, 469-489.

McKinsey and Company (1993), Emerging Exporters: Australia's High Value-Added Manufacturing Exporters, Melbourne: Australian Manufacturing Council.

McNaughton, R. B. (2003), The Number of Export Markets that a Firm Serves: Process Models versus the Born-Global Phenomenon, Journal of International Entrepreneurship, 1 (3), 297-311.

Oviatt, B. M., and P. P. McDougall (1994), Toward a Theory of International New Venture, Journal of International Business Studies, 25 (1), 45-64.

Papke, L. E., and J. M. Wooldridge (1996), Econometric Methods for Fractional Response Variables with an Application to 401(K) Plan Participation Rates, Journal of Applied Econometrics, 11 (4), 619-632.

Penrose, E. (1959), The Theory of the Growth of the Firm, Oxford: Basil Blackwell.

Pregibon, D. (1979), Data Analytic Methods for Generalized Linear Models, Ph.D. Dissertation, University of Toronto.

Reid, S. (1983), Firm Internationalization, Transaction Costs and Strategic Choice, International Marketing Review, 1 (2), 44-56.

Roberts, M. J., and J. R. Tybout (1997), The Decision to Export in Columbia: An Empirical Model of Entry with Sunk Costs, The American Economic Review, 87 (4), 545-564.

Simon, H. (1996), Die heimlichen Gewinner: Die Erfolgsstrategien unbekannter Weltmarktführer (Hidden Champions), Frankfurt/Main: Campus.

Storey, D. J., and B. Tether (1996), A Review of the Empirical Knowledge and an Assessment of Statistical Data on the Economic Importance of New Technology-Based Firms in Europe, Coventry: Warwick Research Institute.

Stump, R. L., G. A. Athaide, and A. W. Joshi (2002), Managing Seller-Buyer New Product Development Relationships for Customized Products: A Contingency Model Based on Transaction Cost Analysis and Empirical Test, Journal of Product Innovation Management, 19 (6), 439-454.

Sullivan, D. (1994a), The “Threshold of Internationalization:” Replication, Extension, and Reinterpretation, Management International Review, 34 (2), 165-186. 
Sullivan, D. (1994b), Measuring the Degree of Internationalization of a Firm, Journal of International Business Studies, 25 (2), 325-342.

Teece, D. J., G. Pisano, and A. Shuen (1997), Dynamic Capabilities and Strategic Management, Strategic Management Journal, 18 (7), 509-533.

Verwaal, E., and B. Donkers (2002), Firm Size and Export Intensity: Solving an Empirical Puzzle, Journal of International Business Studies, 33 (3), 603-613.

Wagner, J. (1995), Exports, Firm Size, and Firm Dynamics, Small Business Economics, 7 (1), 29-39.

Wagner, J. (1996), Export Performance, Human Capital, and Product Innovation in Germany: A Micro View, Jahrbuch für Wirtschaftswissenschaften / Review of Economics, 47, 40-45.

Wagner, J. (2001), A Note on the Firm Size - Export Relationship, Small Business Economics, 17 (4), 229-237.

Wagner, J. (2003), Unobserved Firm Heterogeneity and the Size-Exports Nexus: Evidence from German Panel Data, Review of World Economics, 139 (1), 161-172.

Wakelin, K. (1997), Trade and Innovation: Theory and Evidence, Cheltenham and Northampton: Edward Elgar.

Wernerfelt, B. (1984), A Resource-Based View of the Firm, Strategic Management Journal, 5, 171-180.

Williamson, O. E. (1985), The Economic Institutions of Capitalism, New York: Free Press. 


\section{Appendix}

Table 7: Definition of High-Tech Sectors

\begin{tabular}{|c|c|c|}
\hline $\begin{array}{l}\text { Aggregated } \\
\text { industries used }\end{array}$ & NACE Rev. 1 & Short description according to NACE Rev.1 \\
\hline $\begin{array}{l}\text { R\&D-Intensive } \\
\text { Service Industries }\end{array}$ & $\begin{array}{l}64.20 ; 72.20 \\
72.30 ; 72.40 \\
72.60 ; 73.10\end{array}$ & $\begin{array}{l}\text { Telecommunication, Computer Programming and Software Services, Data } \\
\text { Processing, Misc. Computer Services, R\&D in Natural Sciences and Engineer- } \\
\text { ing }\end{array}$ \\
\hline ICT-Hardware & $\begin{array}{l}30.01 ; 30.02 \\
32.20 ; 32.30\end{array}$ & $\begin{array}{l}\text { Office Equipment; Computers and other Information Processing Equipment; } \\
\text { Television and Radio Transmitters and Apparatus for Line Telephony and Line } \\
\text { Telegraphy; Television and Radio Receivers, Sound or Video Recording and } \\
\text { Reproducing Apparatus }\end{array}$ \\
\hline $\begin{array}{l}\text { Engineering } \\
\text { Industries }\end{array}$ & $\begin{array}{l}33.20 ; 33.30 ; \\
33.40\end{array}$ & $\begin{array}{l}\text { Electronic Instruments and Appliances for Measuring, Checking (except Indus- } \\
\text { trial Process Control); Electronic Industrial Process Control Equipment; Optical } \\
\text { Instruments; Photographic Equipment }\end{array}$ \\
\hline $\begin{array}{l}\text { Health and Life } \\
\text { Sciences }\end{array}$ & $\begin{array}{l}24.41 ; 24.42 ; \\
33.10\end{array}$ & $\begin{array}{l}\text { Pharmaceutical Products and Preparations; Medical and Surgical Equipment and } \\
\text { Orthopaedic Appliances }\end{array}$ \\
\hline $\begin{array}{l}\text { Other High-Tech } \\
\text { Manufacturing }\end{array}$ & $\begin{array}{l}24.16 ; 24.17 \\
31.10 ; 31.20 \\
32.10 ; 35.30\end{array}$ & $\begin{array}{l}\text { Plastics and Synthetic Rubber in Primary Form; Electric Motors, Generators and } \\
\text { Transformers; Electricity Distribution and Control Apparatus; Electronic Valves, } \\
\text { Tubes and other Components; Aircraft and Spacecraft Manufacturing }\end{array}$ \\
\hline
\end{tabular}

Source: Manufacturing sector: Butchart (1987); service sector: Bürgel et al. (2004). 
Figure 1: Predicted Degree of Internationalisation in Dependence of the Number of Employees

\section{Pooled Sample}

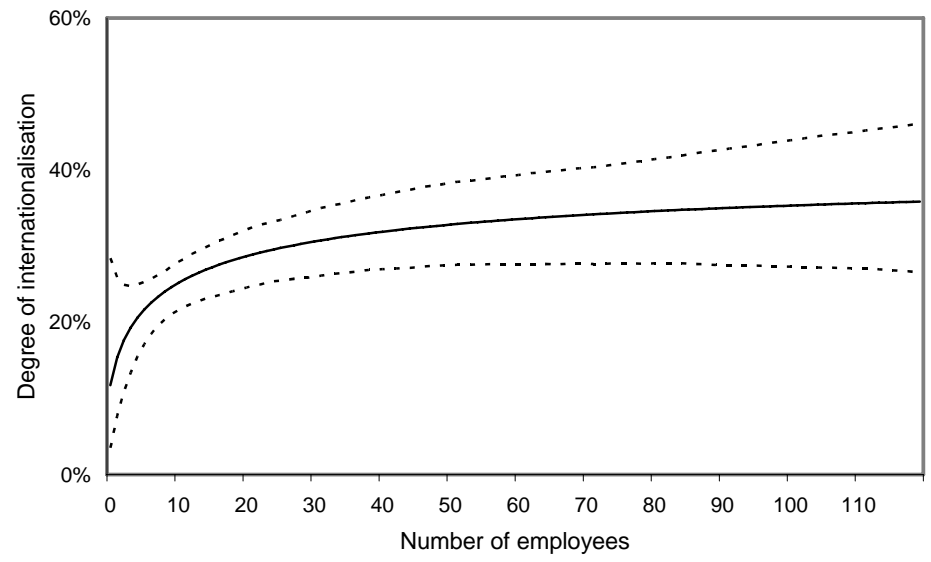

1997

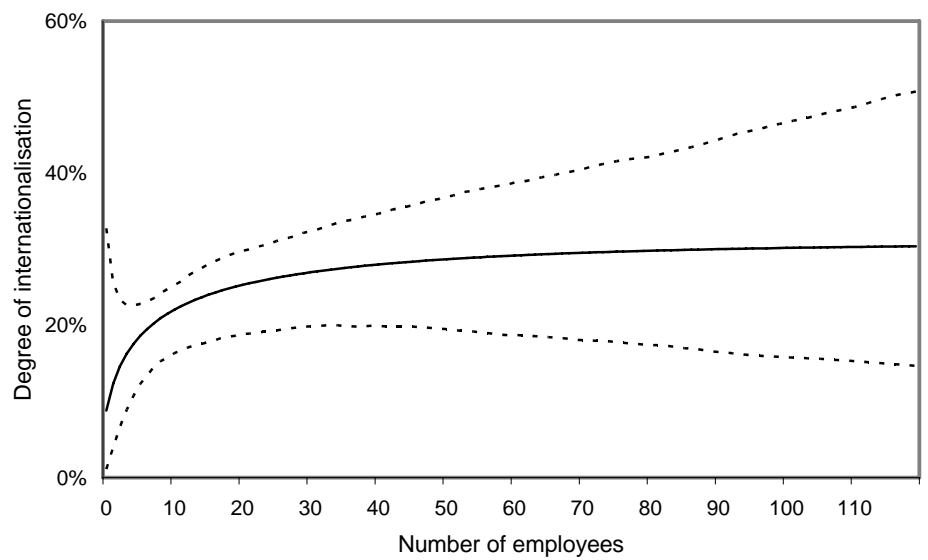

2003

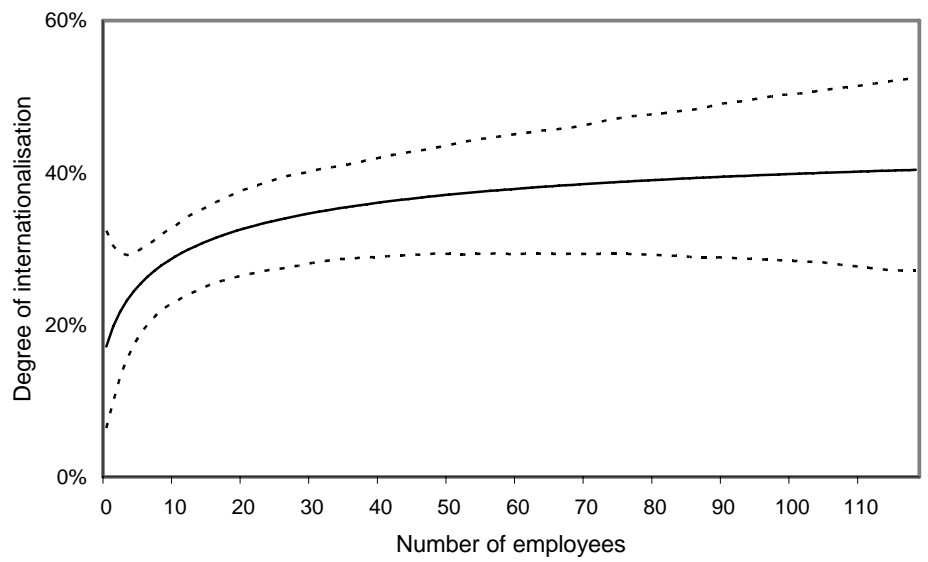

Solid line: predicted degree of internationalisation in dependence of the number of employees, all other variables set to their mean.

Dotted lines: simulated 90\% confidence interval, using the 5\% and 95\% percentiles of the bootstrap distribution (1,000 replications).

Source: own calculation. 